\title{
ROLUL BIOLOGIEI COMPUTATIIONALE ÎN ORGANIZAREA ȘI INTEGRAREA DATELOR DESPRE BIODIVERSITATEA ORGANISMELOR
}

\author{
Sîtnic Victor, Nistreanu Victoria \\ Institutul de Zoologie al AȘM, Chișinău, Republica Moldova, \\ sitnic.md@gmail.com
}

https://doi.org/10.53937/9789975315975.24

Biologia computațională este o știință modernă care implică utilizarea algoritmilor și metodelor informatice pentru analiza, organizarea, integrarea și modelarea datelor și sistemelor biologice. În biologie există două arii mari care generează cantități enorme de date: biologia moleculară și biodiversitatea. Acumularea acestora crește în ritm exponențial și necesită dezvoltarea și aplicarea inițiativelor care au ca scop cercetările și avansările în acest domeniu. Computerizarea vastelor cantități de date biologice și implicarea graduală a tehnologiei informaționale în știința biologică permite utilizarea algoritmilor și domenelor de date ceea ce favorizează semnificativ comunicarea dintre cercetători, dezvoltarea strategiilor de conservare a speciilor periclitate, cunoașterea mai bună a vectorilor și gazdelor bolilor infecțioase, descoperirea de noi populații sau specii și stabilirea rolului acestora în ecosisteme. Exemple specifice de tehnici informatice și direcții de cercetare în studiul, managementul și conservarea biodiversității sunt: Sistemele Informaționale Geografice (GIS), Modelarea Distribuției Speciilor, Modelarea Proceselor Ecologice, Analiza Populațional-Genetică, Analiza Filogenetică, etc. În cadrul cercetărilor recente au fost utilizate primele două tehnici pentru crearea hărților GIS și Modelarea 
Distribuției Spațiale a unor specii rare, cum este chițcanul de mlaștină - Neomys anomalus (fig.1).
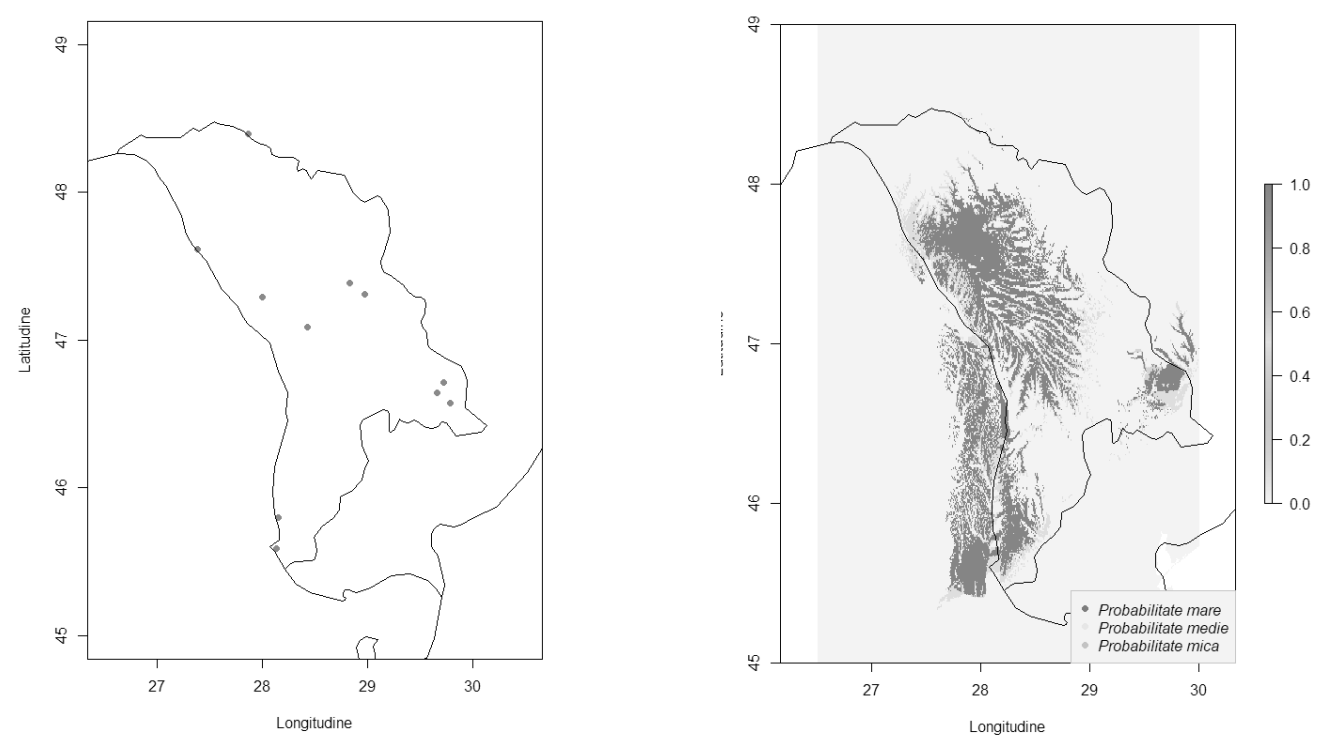

Figura 1. Distribuția cunoscută (stânga) și modelul predictiv al distribuției (dreapta) pentru specia Neomys anomalus în Republica Moldova

Pentru realizarea obiectivelor propuse a fost utilizat mediul de programare R și algoritmul Bioclim. R este o platformă gratuită de facilități software pentru manipularea, calculul și reprezentarea grafică a datelor, fiind considerat de mulți biologi un instrument fundamental în cercetările lor [1]. Cu ajutorul librăriilor și algoritmilor specifici acesta permite modelarea datelor brute, generarea hărților GIS de înaltă calitate precum și construirea modelelor predictive. Algoritmul Bioclim este un model euristic capabil de a realiza predicții cu un număr redus de locații cunoscute și care implică utilizarea a 19 variabile bioclimatice [2]. Modelele de distribuție spațială a speciilor sunt modele corelative. Acestea corelează prezența observată a unei specii cu valorile variabilelor de mediu ale 
acelor locații. Măsura în care un astfel de model va reflecta situația reală a distribuției speciilor depinde de un șir de factori precum: date de intrare suficiente și corecte, algoritmul utilizat, tipul reliefului și a vegetației, dispersia biologică, interacțiunile biotice ș.a.

Biodiversitatea este extrem de importantă pentru supraviețuirea omului și este cea mai prețioasă și fragilă resursă de pe pamânt. Conceptul de biodiversitate implică multitudinea de date despre organizarea și diversitatea vieții, despre interacțiunile organismelor între ele. Aceste interacțiuni pot avea loc de la scale mici la nivelul genelor și cromozomilor până la scale mari, la nivelul organismelor și ecosistemelor. Integrarea și procesarea acestor date atât de variate necesită instrumente complexe de analiză care sunt fie în curs de dezvoltare fie la nivel conceptual. Bioinformatica privind biodiversitatea apare sub forma unui ansamblu de tehnici informatice care lărgesc abordările bioinformatice tradiționale prin integrarea datelor complexe despre viață și se referă la studiul holistic al vieții pe Pământ. Deși acest lucru nu este o sarcină deloc ușoară și necesită mult efort și implicare, accesul facil la date și utilizarea instrumentelor de analiză informatică va schimba în mod fundamental abordarea problemelor de către cercetători.

Studiul a fost efectuat în cadrul proiectului fundamental 15.187.0211F realizat la Institutul de Zoologie.

\section{Referințe}

1. R Development Core Team (2008). R: A language and environment for statistical computing. R Foundation for Statistical Computing, Vienna, Austria. ISBN 3-900051-07-0, URL http://www.R-project.org.

2. WORLDCLIM - a set of global climate layers (climate grids) by Robert J. Hijmans, Susan E. Cameron, Juan L. Parra, Peter G. Jones, Andy Jarvis 